\title{
Acute Human Parvovirus B19 Infection an Immunocompetent Female Adult: A Case Report
}

\author{
Carlos José Atencia Flórez ${ }^{1 *}$ and Catalina Quintero Valencia ${ }^{2}$ \\ ${ }^{1}$ Professor Internal Medicine Department - University of Antioquia. Hospital Universitario San Vicente Fundacion, Colombia \\ ${ }^{2}$ Microbiologist MSc., Internal Medicine Department - LIME. University of Antioquia, Colombia
}

\begin{abstract}
Acute human Parvovirus B19 infection is a well-known cause of infectious erythema in pediatric age. However, in adult patient clinical picture is different but characteristic presenting with erythema, acute polyarthritis, systemic inflammation, hepatic enzymes elevation and anemia. Here, we present a case report about a nonpregnant immunocompetent adult female with a compelling symptom and a serological confirmation also a suspected close epidemiological contact was an infant with infectious erythema. We describe the clinical spectrum of this infection. To recognize its clinical picture and laboratory abnormalities, as well as the infant as a close contact, should make the clinician consider acute human parvovirus B19 infection as main differential diagnosis.
\end{abstract}

KEYWORDS: Human Parvovirus B19; Arthritis; Infectious erythema

\section{CASE REPORT}

A 33-year-old women was admitted as inpatient complaining 3-day fever, malaise, headache, myalgia and nausea. For two days, she started right knee and left ankle pain, with limitations for movements and then bilateral elbow, wrist and metacarpophalangeal pain and edema with complete movement limitation (Figure 1). Also, she noted macular erythema involving her abdomen, torso thighs and arms. She also passed 3 liquid stools.

Her past medical history was unremarkable, except for a close contact with her 2-year-old nephew who suffered a febrile illness associated with exanthema (Figure 2) She didn't mention any mosquito's bites.

Her vital signs were normal, she was eutrophic and alert. There was no alopecia, $0.5 \mathrm{~cm}$ posterior cervical nodes were palpable, conjunctival injection was noted., there were no oral ulcers. Cardiopulmonar examination was unremarkable. In the abdomen there were no hepatomegaly nor splenomegaly.

Extremities pains were elicited when elbow, wrist and metacarpophalangeal joints were palpated. Pain was also evident when passive joint movement. There were no tenosynovitis. Skin showed erythematous and confluent macular lessions in abdomen, back, arms and thighs. There were no pruritus signs and no purpuric rash (Figure 3). There were no vaginal discharge. She was evaluated by Internist, who considered judging by the clinical picture involving fever, rash and polyarthritis the first diagnosis was a viral origin acute polyarthritis. Laboratory blood sample were taken including complete blood count, inflammatory reactants, and basic biochemistry were taken. Also, autoimmune and viral serology were ordered and acute Parvovirus B19 infection was made as definite diagnosis (Table 1).

Two weeks after discharged the patient recovered uneventfully. She was given oral nonsteroidal anti-inflammatories and prednisolone $10 \mathrm{mg}$; this medication was suspended after one week. She developed carpal tunnel syndrome 2 months later.

\section{REVIEW}

Parvovirus B19 is a DNA virus belonging Parvoviridae virus family and Erythroviridae genera. Widespread geographical distribution and human infections is presented sporadically or in clusters [1]. Human is the only known host and its transmission occurs by respiratory secretions (common in schools and kindergarten) but transplacentary and hemocomponents routes has been also described.
Quick Response Code:

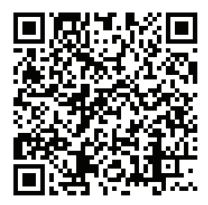

Address for correspondence: Carlos José Atencia Flórez, University of Antioquia, Colombia; ORCID 0000-0002-4531-229X

Received: July 27, $2021 \quad$ Published: October 01, 2021

How to cite this article: Atencia C, Quintero C. Acute Human Parvovirus B19 Infection an Immunocompetent Female Adult: A Case Report; ORCID 0000-0002-4531-229X. 2021- 3(5) OAJBS.ID.000325. DOI: $10.38125 /$ OAJBS.000325 
Clinical presentation varies depending on the host. In children infectious erythema is the main clinical picture also known as "fifth illness" with slapped cheeks-; in adult patient arthralgia and arthritis is the most frequent clinical manifestation [2]; in pregnant women fetal anemia, nonimmune fetal hydrops and intrauterine death and in immunocompromised patients or who suffer chronic hemolysis pure erythroid aplasia is the clinical picture. Other clinical involvement described in literature has been encephalitis, peripheral nerve, hepatitis and myopericarditis [1,2].
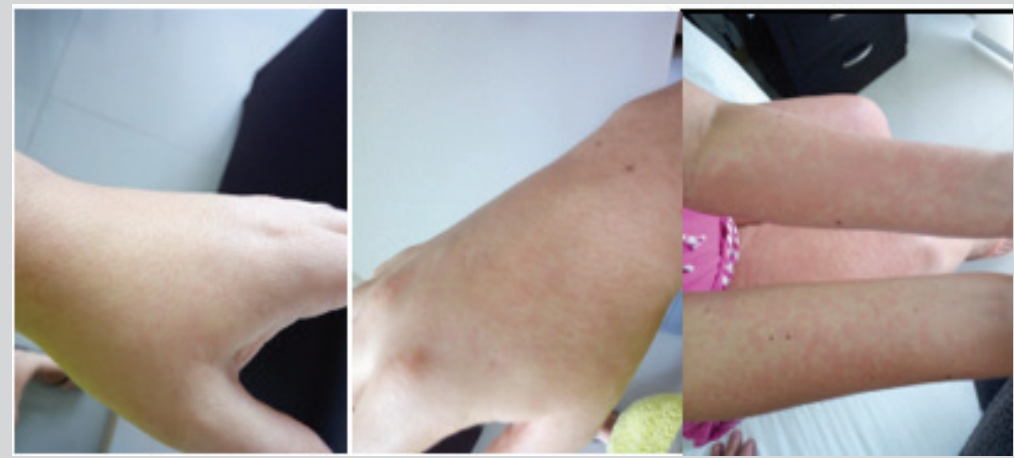

Figure 1: Articular manifestations.

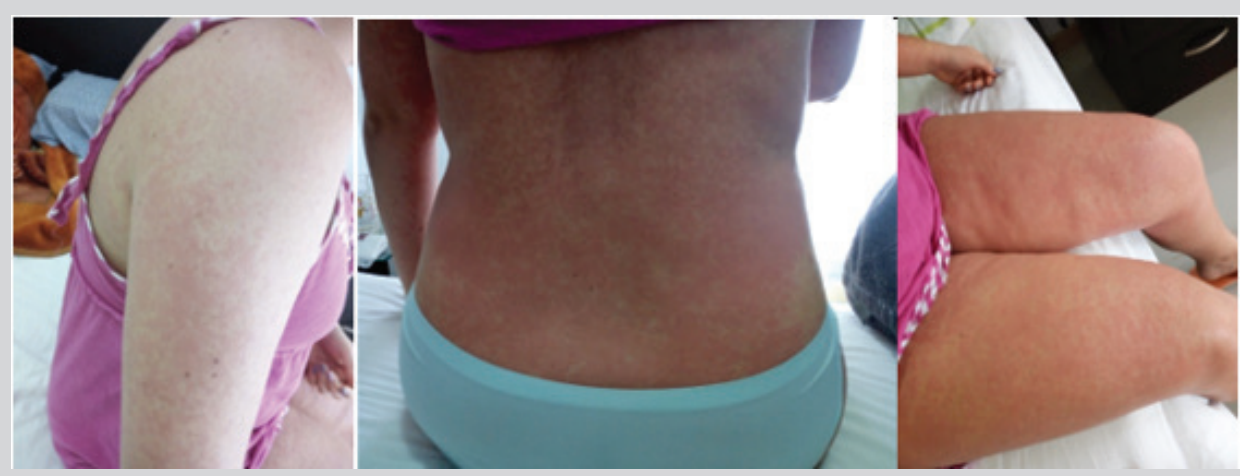

Figure 2: Cutaneous manifestations.

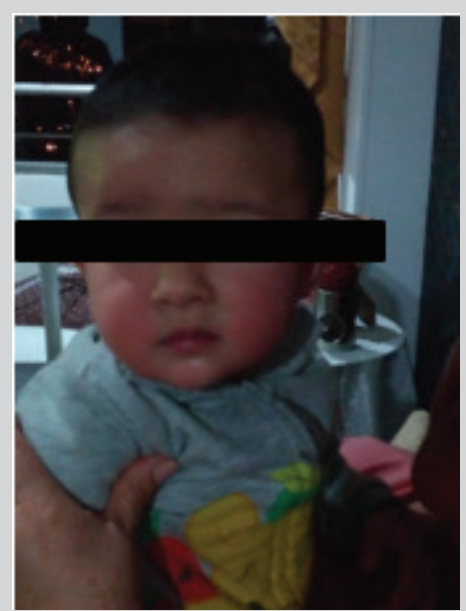

Figure 3: Infant close contact in recent days with the patient. Slapped cheeks can be noted.

Acute Parvovirus B19 infection is frequent. However, is rare and probably underdiagnosed in adult patient because nonspecific symptoms [3]. Mean age of presentation is from 30s to 40s in women predominantly, in $50 \%$ of cases a close contact with an infant with fifth illness can be documented. As in the case we presented above, fever, arthralgia and arthritis can be seen in $75 \%$ of cases, also erythematous macular rash, lynfopenia with anemia which resolves in less than 2 weeks in $75 \%$ of the cases, increased acute inflammatory reactants and liver enzymes elevation in $87 \%$ of patients [4]. Sometimes peripheral nerve involvement remains as sequela, as was in our case report [5]. In immunocompetent host diagnosis can be confirmed with positive serologic IgM test for Parvovirus [6].

\section{CONCLUSION}

As a conclusion, in adult otherwise healthy patient presenting with fever, acute polyarthritis, anemia or leucopenia, inflammation and increased liver enzymes and close contact with a suspected infant with "fifth illness", acute Parvovirus B19 infection must be considered between differential diagnosis. 


\section{ETHICAL CONSIDERATIONS}

The Hospital Universitario SanVicente Fundacion Ethical and Research Committee approved the Case Report by Act 19-2021. Also the patient and the parents of the case contact read, understood and signed the Informed Consent to publish the case.

Table 1: Laboratory blood test of the case, IgM, Immunoglobulin M. IgG, Immunoglobulin G. VDRL, Venereal Disease, Research Laboratory. ELISA, Enzyme linked immunosorbent assay. CMIA, Chemiluminescent microparticle enzyme immunoassay. ECLIA, Electrochemioluminiscent immunoassay.

\begin{tabular}{|c|c|}
\hline Leucocytes & $8400 / \mathrm{mm}^{3}$ \\
\hline Neutrophils & $7100 / \mathrm{mm}^{3}$ \\
\hline Linfocytes & $800 / \mathrm{mm}^{3}$ \\
\hline Hemoglobin & $12 \mathrm{gr} / \mathrm{dl}$ \\
\hline Hematocrit & $39 \%$ \\
\hline Red blood cells count & $4680000 / \mathrm{mm}^{3}$ \\
\hline Mean corpuscular volumen & $85 \mathrm{Fl}$ \\
\hline Mean corpuscular hemoglobin & $33 \mathrm{pg}$ \\
\hline Platelets count & $401000 / \mathrm{mm}^{3}$ \\
\hline Peripheral blood smear & Normal \\
\hline Direct Coombs test & Negative \\
\hline $\begin{array}{r}\text { Ferritina } \\
\end{array}$ & $225 \mathrm{ng} / \mathrm{ml}$ \\
\hline C Reactive protein (immunoturbidimetry) & $10,6 \mathrm{mg} / \mathrm{dl}$ \\
\hline Globular sedimentation rate VSG (Westergreen) & $49 \mathrm{~mm} / \mathrm{hr}$ \\
\hline Aspartate aminotransferase AST (chemistry method) & $100-57 \mathrm{UI} / \mathrm{L}$ \\
\hline Alanine aminotransferase ALT (chemistry method) & $166-105 \mathrm{UI} / \mathrm{L}$ \\
\hline Gamma glutamyl transpeptidase GGT (chemistry method) & $202 \mathrm{UI} / \mathrm{L}$ \\
\hline Lactate dehydrogenase LDH (chemistry method) & $363-290 \mathrm{UI} / \mathrm{L}$ \\
\hline Hepatitis A Virus IgM (CMIA) & Negative \\
\hline Hepatitis B Virus S antigen (CMIA) & Negative \\
\hline Hepatitis C Virus antibodies (CMIA) & Negative \\
\hline Ebstein Barr virus IgM (microELISA) & Negative \\
\hline Dengue virus IgM and NS1 antigen & Negative \\
\hline Chickungunya virus IgM (ELISA) & Negative \\
\hline VDRL & No reactive \\
\hline Citomegalovirus IgM (CMIA) & Negative \\
\hline Human Parvovirus B19 IgM (ECLIA) & Positive (Index 41) \\
\hline Human Parvovirus B19 IgG (ECLIA) & Positive (Index 12) \\
\hline Human immunodeficiency Virus (ELISA) & Negative \\
\hline Complement C4 (immunoturbidimetry) & $10 \mathrm{mg} / \mathrm{dl}$ \\
\hline Complement C3 (immunoturbidimetry) & $106 \mathrm{mg} / \mathrm{dl}$ \\
\hline Uroanalysis & Normal \\
\hline 24hr-Proteinuria (turbidimetry) & $200 \mathrm{mg}$ \\
\hline Reumatoid Factor (immunoturbidimetry) & 7,5 UI/ml Negative \\
\hline Antinuclear antibodies ANA (ELISA) & Negative \\
\hline Nuclear extractable antigen antibodies (ELISA) & Negative \\
\hline
\end{tabular}

\section{REFERENCES}

1. Torné J, Blanch J, Garcia X, Baucells JM (2008) Parvovirus B19 infection in immunocompetent adult patients. Med Clin (Barc) 130(2): 78.

2. Drago F, Ciccarese G, Agnoletti AF, Cogorno L, Muda A, et al. (2015) Remitting seronegative symmetrical synovitis with pitting edema associated with parvovirus B19 infection: two new cases and review of the comorbidities. Int J Dermatol 54(10): e389-393.

3. Lavoipierre V, Dellyes A, Aubry C, Zandotti C, Lafforgue P, et al. (2016) Acute polyarthritis in a young patient caused by meningococcal and parvovirus B19 infections: a case report and review of the literature. J
Med Case Rep 10(1): 362.

4. Drago F, Semino M, Rampini P, Rebora A (1999) Parvovirus B19 infection associated with acute hepatitis and a purpuric exanthem. Br J Dermatol. 141(1): 160-161.

5. Musiani M, Manaresi E, Gallinella G, Zerbini M (2007) Persistent parvovirus b19 infection resulting in carpal tunnel syndrome. J Clin Pathol 60(10): 1177-1178.

6. Korman AM, Alikhan A, Kaffenberger BH (2017) Viral exanthems: An update on laboratory testing of the adult patient. J Am Acad Dermatol 76(3): 538-550 